SHS Web of Conferences 2, 00010 (2012)

DOI: $10.1051 /$ shsconf $/ 20120200010$

(C) Owned by the authors, published by EDP Sciences, 2012

\title{
Challenges of post-socialism suburb: The case of Pieriga
}

\author{
G. Darbina
}

Rīga Stradinš̌ University, Latvia

\begin{abstract}
The construction of new private suburban houses at the Pieriga (the suburban zone surrounding the capital city of Riga) that was affected by the land market created building territories that do not have a common planning or infrastructure. The suburbanization process of Pieriga took place on the territories of agriculture, former gardening societies and partly at the forests. By creating the building territories that lacked an architectonic or a social conception, it was forgotten that the transformation of the land includes not only the visual changes but also the changes of lifestyles. Because of the growth of the number of the inhabitants in Pieriga, the commuting to Riga and to other cities is also increasing. A quantitative research work shows that in Latvia Pieriga is a desired place of residence. The life in the suburb has become a form of the consumption of the status that is still built on the hopes of and upward mobility.
\end{abstract}

Key words: suburb, suburbanization, migration, private suburban house, solidarity

Before the economical crisis many Latvian families were striving to acquire their own house: during the soviet period there were families that shared their houses with other generations. During the last years the biggest growth of the number of the inhabitants related to the construction of new houses was observed at Pieriga - the suburb of the Riga city. During the year 2009 over 13000 inhabitants came to live at the Pieriga's statistical region. The expansion of the suburb during the last decade was also affected by the easily accessible mortgages. During the economical growth the suburbanization of Pieriga was also facilitated by migrating middle class families, because the estate prices were very high. The life at the suburb became a way of consumption of the status that were based on the upward mobility.

The research work of Contor on 1084 regions of the European Union showed that Pieriga was the $6^{\text {th }}$ most perspective to have an economical growth (LETA, 22.01.2010). However the construction of new houses and the rapid economical growth has taken place because of the influence of the land market and it created scattered construction territories that do not have a common planning or an infrastructure. It also created the so called meadow-villages that are not developing anymore. Now after the administrative territorial reform of the year 2009, the Pieriga is formed by 17 areas: Adazi, Babite, Baldone, Carnikava, Garkalne, Incukalns, Krimulda, Kekava, Malpils, Marupe, Olaine, Ropazi, Salaspils, Saulkrasti, Seja, Sigulda, Stopini.

The aim of the research work is to study how the social processes of Pieriga are affected by the new construction.

The research work is based on the analysis and the conclusions of two other researches: "The distribution of the population of Pieriga" (Pužulis and Šķiņķis, 2009) and the "Attitude of the inhabitants to the life in their local government" (SKDS, 2009).

The main terms are the inner migration of a country and suburbanization.

The inner migration of a country - the inhabitants are migrating only in their own country. The inner migration doesn't change the number of the inhabitants in the whole country, although it changes the territorial placement. The country affects the progress of the migration directly or indirectly. The process of the migration is determined by the distribution of the investments and differentiation and from the standard of living of the inhabitants (Abercrombie et al., 1997).

This is an Open Access article distributed under the terms of the Creative Commons Attribution License 2.0, which permits unrestricted use, distribution, and reproduction in any medium, provided the original work is properly cited. 


\section{SHS Web of Conferences}

Suburbanization or the urbanization to the suburbs is a development process of the suburbs surrounding the territories of the big cities and metropolises (CEMAT Glossary). In the suburbs people do not aim for the diversity of the social contacts that they previously acquired at the society of the village or the ambit.

\section{Urbanization and the modern society}

The urbanization and the suburbanization have been and still are being researched very often. The classics of the sociology Ferdinand Tonnies and Georg Simmel examined the social and the psychological changes, brought by the development of urbanization and capitalism in the Europe (Morrison, 2006). Emile Durkheim studied the initial collapse of the bonds of the community affected by the divisions of the labor in society, as well as the changes of the common conscience and the solidarity, that affected the formation of the cities. The theoretical work of Emile Durkheim "Division of labor in society" was the first one who started the way of thinking about the development of the society, by looking at the links between the individuals on the society, as well as the mutual links between the individuals. Durkheim also studied how this connection affects the cohesion of the society. 'The main problem of the research is "why do individuals, while becoming more autonomous, depend more upon society? How can they be at once more individual and solidary?" (Morrison, 2006, p.128). The term "solidarity" is comprehended by Durkheim in various ways. Durkheim describes two different solidarities: organic and mechanical and identifies two different societies that correspond to different forms of solidarity: the segmented society and the advanced society. The segmented society is made of small but mutually connected groups in a defined social territory. Here the solidarity is mechanicalit is based on roots of the common identity and the individual is directly connected to the society through the dependence on it. The collective conscience is based on the religious standards and performs the regulation functions of the individuals (Morrison, 2006). The main characteristics of the advanced society are based on the bigger number of the inhabitants, which are scattered in a larger geographical space, as well as on the development of the near cities and divisions of labor. In these conditions the society has a wider field of view and it is more differenced. The advanced society is characterized by the organic solidarity that is based on a high density of the inhabitants and the development of the cities (Morrison, 2006). In this society the individuals are more mutually connected through agreements, not through feelings and duties, and the place in the society is defined by the employment no by the family bonds (Lin and Mole, 2005).

\section{The suburbanization processes in Pieriga}

The Research on the structure of the distribution of the population in Pieriga (Pužulis and Šķiņı̧is, 2009) was done in the supervision of the Riga planning region in summer and autumn of year 2009. It was the first attempt to study the structure of the distribution of the population as an element of the distribution of the population in Pieriga in the years of independence. The suburbanization process of Pieriga district took place on the territories of agriculture, former gardening societies and partly at the forests. New urbanized territories are forming around Riga with functional and landscape features. A short description of the territories:

Marupe - a territory that is located near Riga and has two historical tendencies of urbanizationbroadening the physical borders of Riga and the development and progression of Jaunmarupe - a village of Pieriga. Between these two poles a transitional territory is shaping, that is developing as a new territory of economy and distribution of population without a status of settlement. "Olaines darzini" - corporatives of horticulture that are physically isolated in a forest far from other settlements - a partial transformation to a settlement with a status of village is characteristic to this territory. Kekava-Valdlauci-a typical urbanization territory of Pieriga is located next to the RigaBauska road. Adazi-Carnikava-"the new city" in Pieriga that is developing with a center in Adazi 


\section{Int. Conf. SOCIETY. HEALTH. WELFARE; Congr. of Rehabilitation Doctors of Latvia}

and an unstructurised construction in almost every part of the local government territory. Suzi-Bergi-a direct territory of Pieriga with a varied history of transformation and problems. Ropazi-a more distant territory of Pieriga with many formally built perspective villages and small tendencies of development. Saulkrastu darzini-a territory of corporatives of horticulture in the rural area of Saulkrasti, with a perspective status of village (Pužulis and Šksinskis, 2009).

When evaluating the new construction in Pieriga, we have to conclude that during the last years the local governments have had a misinterpreted comprehension about the development of territories that was based on the speculative business of the market and was often supplemented with the inability to work with the investors. The result is that Pieriga is formed by a network of a distribution of population, that is formed by each of the local government and that has inner competition. By making the construction territories that had no architectonic or social conception in Pieriga, it was ignored that the transformation includes not only the visual changes but also the changes of lifestyles (Pužulis and Šksinķis, 2009).

Within the framework of the doctoral work, the author of the research work together with the research center SKDS made a quantitative study on the residents' attitude to the life in Pieriga (Riga district). The results of the research work show that in general the inhabitants are satisfied with the life in their local government: the vast majority $(81 \%)$ would recommend their friends to life in Pieriga. Residents were mainly satisfied with the ecological environment (on average $81 \%$ of the residents of the Riga district were satisfied), the commodity and the cleanliness (80\%), the development of the city and the district (74\%). But the possibilities to find a job were evaluated the most critically-only $8 \%$ were satisfied with it. In order to compare the satisfaction with these spheres a satisfaction index was developed: an index that shows the average, positive and negative evaluation difference in the analyzed spheres in every local government. The data show that the highest satisfaction index was in the Babite parish (47 points), but the lowest in Olaine parish (16 points). The study also shows that the inhabitants of the Riga district evaluate their possibilities to change the decisions that affect their lives and environments of the local governments very sceptically: on average only $10 \%$ of the respondents thought that they can change these decisions to great extent, but most of the people $(59 \%)$ said that they think that they can affect these decisions only slightly. When describing the connection with their residence, $54 \%$ of the respondents said that they attend the cultural and entertainment activities in their local government and 5\% of the respondents are engaged in a non governmental organization, congregation or amateur performances of their local government.

The comparatively weak bond to the place of residence can be explained by the specific pattern of creation of the suburban zones in Latvia. Many families have loans and low incomes. Thus many families by moving to a suburb reach a downward mobility. The quantitative research work shows that Pieriga is a desired place of residence in Latvia but a deeper comprehension and attitude on their place of residence, as well as the social bonds between the inhabitants will be possible to clarify only by making deeper interviews.

\section{The concept of the suburb as the place of residence}

The suburbs have developed differently in different countries. A research shows a concept of an ideal house of the London suburb that emerges at the same time as the consumer society in England during years 1920.-1950. at the same time when the concept of the consumer housewife developed.

Approximately the same time - 70 years ago in Pieriga in a forest an unusual village, called "Uzvaras lidums" (victory clearance) was built. The construction was monitored by the whole country. In 1936 in the halfway from Riga to Jelgava at the Olaine parish it was decided to build a complex of new houses in an area of 250 hectares. A new straight road between the highroad and the village was also built. 160 construction workers saw the wood and left it for the next owner and then in the right time chopped the wood for the houses. About 70 men dug the ditches. In "Uzvaras līdumi" the households were intended to be built for the participants of the Latvian fights of the freedom. About 100 applicants signed up and 


\section{SHS Web of Conferences}

16 families were chosen. The project intended that there was an alley to every yard, by the gate on the left side there was place for a lime tree, an oak on the right side, a place for the fruit garden at the south side and at the north side a greenery of firs. A place for the mast for the flag was also intended. The migrants from different districts of Latvia were able to become friends, helped each other and there is a special aura, that can be still felt at this village, surrounded by the forest (Darbina, 2009).

The Russian research worker T.Barcunova has studied the concept of the private house in correspondence with post soviet nostalgia in Novosimbirsk and concluded that there is another tendency: the overstatement of the comprehension of home. It is connected with the discourse of the privacy and the remaking of the social field. Barcunova has studied the Anastasia movement, that can be seen in many cities in Russia, and its social praxis on a model of village, that is build of many private houses - family manors. The ambitions in the Russian publishing to construct a house as a symbol, that would be able to stand against the social uncertainty started at the 90-ties in correspondence with the privatization of the land. The main thought of the Anastasia movement: to create family houses without the characteristics of a city in suburbs or in territories that are further from the city. The sense of the conception: a healthy person can originate and be born only in a house that has been built by his parents. The cottage "daca" of the soviet times in this conception is the prototype of the family villa. Unlike the "dača" cottages, the conception of the family villa intends a life of all generations together and the land of the family villas not being used in a utilitarian way. It offers a free lifestyle without a work in the soviet spirit for growing the food (Barcunova, 2005).

During the last twenty years the concepts of belonging to a place have changed. "Local is as much global as it is local" - the classical message of Doreen Massey (Massey, 1991; McDowell et al., 2006) is supplemented by the view of Mike Savage (2005) that the idea of the community and the belonging to a place should be replaced with a concept of the elective belonging, at least at the researches on the middle class. The belonging to the place of residence for the urban middle class is not connected with being born or the family house. It is chosen in correspondence with the story of the life and the incomings. The belonging to the place is connected with the self evaluation, the possibilities of raising the children and giving them education (McDowell et al., 2006). It characterizes the analyzed advanced society by Durkheim as organic solidarity, where the place in the society is determined by the professional work, not by the family.

During the last years the researches of the suburbs have brought the attention to the shuttle migration - a short term movement there and back that is the most widespread model in the European migration after the year 1989. Very characteristic for the suburbs is the commuter-a person who regularly goes to the work and back by train or car. People live in mobility, as long as it is possible. Simmel calls them the "postmodern migrants" (Scaff, 2011). This kind of lifestyle often ends with immigration, in order to improve or preserve the quality of life at home. Leaving the house and returning becomes a strategy of "existence at home" and actually is an alternative to migration.

\section{Conclusions}

In the West suburbs historically developed as upper and middle-class residential areas where women were primarily seen as housewives, were not expected to work outside home and primarily were seen as objects rather than subjects of status consumption. Transformation of the urban space due to suburbanization has been among the most noticeable processes that have marked the end of socialism in East- and Central Europe. A suburban family house surrounded by a green lawn has come to symbolize a new era as well as a means to claim status and respectability. An active property development in Pieriga (the suburban zone surrounding the capital city of Riga) began at the turn of the new millennium when the real estate market was booming. In recent years about ten thousands inhabitants a year have moved to Pierīga, from either the capital or other regions of the country. The outcome was dozens of widely scattered real property clusters, built with no overarching communal development plan and with none or underdeveloped infrastructure. Very characteristic for the suburbs is the commuter-a person who 
Int. Conf. SOCIETY. HEALTH. WELFARE; Congr. of Rehabilitation Doctors of Latvia

regularly goes to the work and back by train or car. People live in mobility, as long as it is possible. Pierīga, nevertheless, had become a desired place of residence, as a survey of attitudes towards the community life in municipalities demonstrated.

\section{References}

[1] Abercrombie, N., Hill, S., Turner, B.S. (1997) The Penguin Dictionary Of Sociology. UK: Great Britain Penguin Books.

[2] Darbiņa, G. (sast.,red.) (2009) Idejas labākai dz̄̄vei Pierīgā. Rīga: Rīgas rajona padome.

[3] Lin, J., Mole, C. (eds.) (2005) The Urban Sociology. Reader . Routledge.

[4] McDowell, L.,Ward, K., Perrons, D., Ray, K., Fagan, C. (2006) Place, Class and Local Circuits of Reproduction:Exploring the Social Geography of Middle-class Childcare in London. Urban Studies, November 2006; 43(12), p. 2163-2182.

[5] Morrison, K. (2006) Marx, Durkheim, Weber: formation of modern social thought . The Division of Labour in Society (p. 128-151), SAGE Publications.

[6] Pužulis, A., Šķiņķis, P. (2009) Pierīgas apdzīvojuma struktūras izpēte. www.rpr. gov.lv/pub/index.php?id=239

[7] Savage, M., Bagnall, G., Longhurst, B. (2005) Globalisation and Belonging. London: Sage.

[8] Scaff, L.A. (2011) Georg Simmel. In The Wiley-Blackwell Companion to Major Social Theorists: Classical Social Theorists, Volume I (eds G.Ritzer and J.Stepnisky). Wiley-Blackwell, Oxford, UK.

[9] БарчуновА, Т.В (2005) Мой адрес-и дом, и улица. Отношения между поколениями в постсоветский период и изменение концепции загородного дома (на примере движения Анастасийцев). Конференция «Двадиать лет спустя. Советский человек в постсоветском мире»», 14-17 сентября 2005 года. Иркутск.

[10] Commin, the Baltic Spatial Conceptshare. http://commin.org/en/bsr-glossaries/ national-glossaries/latvia/suburbanizacija-urbanizacija-uz-nomalem.html

[11] www.leta/lat/arhivsn 